\title{
Teori Kewirausahaan Destruksi Kreatif: Penghancuran Cara Lama untuk Jalan Baru
}

\author{
Agung Purnomo \\ Program Studi Kewirausahaan \\ Universitas Bina Nusantara \\ agung.purnomo@binus.ac.id
}

Penelitian bidang kewirausahaan di persada nusantara semakin tumbuh dan berkembang (Purnomo et al., 2019). Kewirausahaan (entrepreneurship) merupakan suatu sikap kemampuan, jiwa, dan mental yang selalu aktif guna mengkreasi hal baru yang sangat berguna dan bernilai bagi orang lain, diri, serta meningkatkan pendapatan (Hastuti et al., 2020). Untuk memahami dan mengembangkan pengetahuan kewirausahaan, para ilmuwan melakukan studi dan mengembangkan beberapa teori kewirausahaan.

Salah satu teori kewirausahaan yang berkembang adalah teori kewirausahaan destruksi kreatif (the creative destruction theory of entrepreneurship) yang digagas oleh Joseph A. Schumpeter. Teori kewirausahaan destruksi kreatif memandang wirausahawan sebagai inovator utama dan kewirausahaan adalah pendorong utama ekonomi, menciptakan pertumbuhan ekonomi melalui badai penghancuran kreatif (Schumpeter, 1947).

Schumpeter adalah seorang ekonom Austria yang menulis pada tahun 1930-an tentang sifat kapitalisme. Dia mengkritik pendekatan klasik untuk ekonomi, yang membuat beberapa variabel tetap untuk menyimpulkan kesimpulan melalui logika, terlalu abstrak dan tidak didasarkan pada kenyataan. Ia percaya bahwa kapitalisme hanya dapat dipahami sebagai ketidakseimbangan (disequilibrium) yang disebabkan oleh perubahan terus menerus dari inovasi (Schumpeter, 1947, 1950).

Schumpeter membedakan antara penemu dan pengusaha. Pengusaha adalah pelaku ekonomi yang lebih penting daripada penemu karena pengusaha bertanggung jawab atas implementasi dan penyebaran penemuan yang sebenarnya. Penemu menciptakan teknologi dan teknik baru, sedangkan pengusaha mengubahnya menjadi kekuatan ekonomi (Schumpeter, 1950).

Pemikiran Schumpeter yang paling terkenal karena teorinya tentang penghancuran kreatif yang merayakan penghancuran cara lama, perusahaan, dan warisan untuk membuka jalan bagi yang baru. Teori dinamis Schumpeter kontras dengan teori statis lama tentang aliran sirkuler ekonomi (the circular flow of the economy). Ia mengemukakan bahwa wirausahawan menghasilkan inovasi dengan menciptakan kombinasi baru dengan faktor produksi seperti teknologi dan teknik. 
Pengusaha berinovasi dengan memperkenalkan produk baru, membuka pasar baru, sumber input baru, atau bentuk organisasi baru. Schumpeter dikreditkan dengan menempatkan aktor manusia di pusat proses pembangunan ekonomi. Dia berargumen bahwa wirausahawan berusaha untuk mendapatkan kekuasaan melalui kapasitas untuk melawan tekanan sosial dan untuk mengatasi keterbatasan perangkat keterampilan yang ada. Mungkin salah satu perkiraan modern yang paling dekat dengan gagasan kehancuran kreatif ditemukan dalam teori inovasi yang mengganggu (the disruptive innovation theory) oleh Clayton Christensen (Laplume \& Yeganegi, 2018).

Representasi modern yang hebat dari teori Schumpeter tentang penghancuran kreatif dalam kewirausahaan adalah perusahaan rintisan (start-up) yang inovatif. Startup bertujuan untuk memecahkan masalah yang ada yang dialami oleh pasar dan penawaran incumbent saat ini. Juga, bertujuan untuk menciptakan solusi baru yang pada akhirnya akan mengambil alih produk atau layanan yang ada di pasar dengan menghancurkannya. Hal ini dapat dilihat dari peningkatan layanan streaming seperti Netflix yang secara efektif mendominasi industri hiburan rumah dan membuat bisnis seperti Blockbuster menjadi semakin usang (Stam, 2018).

\section{References}

Hastuti, P., Nurofik, A., Purnomo, A., Hasibuan, A., Aribowo, H., Faried, A. I., Tasnim, T., Sudarso, A., Soetijono, I. K., Saputra, D. H., \& Simarmata, J. (2020). Kewirausahaan dan UMKM. Yayasan Kita Menulis.

https://kitamenulis.id/2020/03/02/kewirausahaan-dan-umkm/

Laplume, A., \& Yeganegi, S. (2018). Creative Destruction Theory of Entrepreneurship.

Entrepreneurship Theories.

https://entrepreneurshiptheories.blogspot.com/p/about-author.html

Purnomo, A., Usman, I., \& Asitah, N. (2019). Penelitian Kewirausahaan di Indonesia :

Pemetaan Publikasi dalam Perspektif Scientometrik (1972-2019). AdBispreneur, 4(3), 207. https://doi.org/10.24198/adbispreneur.v4i3.25021

Schumpeter, J. A. (1947). The Creative Response in Economic History. The Journal of Economic History, 7(2), 149-159. https://www.jstor.org/stable/2113338

Schumpeter, J. A. (1950). Capitalism, Socialism, and Democracy. Harper.

https://www.harpercollins.com/products/capitalism-socialism-and-democracyjoseph-a-schumpeter?variant $=32122832879650$

Stam, E. (2018). Enabling Creative Destruction - An Entrepreneurial Ecosystem Approach to Industrial Policy. https://dspace.library.uu.nl/handle/1874/369844 